\title{
COVID-19 Mengubah Kehidupan Kita
}

\author{
Patrianef Darwis ${ }^{1}$ \\ ${ }^{1}$ Divisi Bedah Vaskular dan Endovaskular, Departemen Ilmu Bedah Fakultas Kedokteran Universitas \\ Indonesia/ Rumah Sakit Cipto Mangunkusumo
}

Sejawat sekalian, tahun 2020 adalah tahun yang berat bagi kita bersama. Bukan hanya bagi kita dibidang kesehatan, tetapi juga mengenai seluruh bidang kehidupan dan bukan hanya di Indonesia tetapi di seluruh dunia. Tantangan yang berat itu diakibatkan kemunculan virus COVID-19 yang mewabah di seluruh dunia.

Wabah COVID-19 ini di bidang kesehatan berpengaruh besar. Terjadi peningkatan kasus COVID-19 ini diseluruh dunia termasuk di Indonesia. Di Indonesia sendiri ada kesan awalnya pemerintah khususnya Kementerian Kesehatan sedikit gagap dan terkesan lambat dalam bertindak. Bahkan untuk proses diagnostik awalnya semua spesimen pemeriksaan swab tenggorokan dipusatkan di satu tempat sehingga untuk konfirmasi diagnosis memerlukan waktu yang lama sehingga proses konfirmasi diagnosis yang diperlukan untuk membatasi penyebaran penyakit dan proses pengobatan sedikit terhambat.

Di sisi lain kita sebagai dokter spesialis jibiikabi.org bedah yang melakukan pelayanan pasien terjadi perubahan besar. Proses pelayanan pasien termasuk pembedahan menyebabkan kita berkontak erat dengan pasien yang selama proses pelayanan bisa saja menderita COVID-19 dengan gejala ringan bahkan tanpa gejala. Demikian juga dokter lain yang tidak melakukan pembedahan. Angka kesakitan dan kematian dokter dan tenaga kesehatan lain meningkat dengan cepat. Angka kesakitan tersebut tinggi selain akibat faktor kontak juga akibat kekurang-siapan kita dalam penyediaan Alat Pelindung Diri (APD) yang diperlukan dalam perlindungan dokter dan tenaga kesehatan selama melayani pasien. Alhamdulillah, kekurangan APD tersebut pelan pelan dapat berkurang dan jumlah kesakitan dan kematian dokter serta tenaga kesehatan perlahan mulai menurun. Sebagai dokter, proses pelayanan pasien yang memerlukan kontak erat dengan pasien menyebabkan kita rentan terkena COVID-19. Selain berpotensi terkena kita sendiri juga berpotensi menyebarkan 


\section{EDITORIAL}

COVID-19 di lingkungan keluarga kita bahkan kepada pasien lain. Untuk itu kita perlu taat dan patuh serta konsisten menggunakan APD yang tepat serta protokol kesehatan lain selama pelayanan pasien.

Kepada sejawat para dokter spesialis bedah, kita harus mengingat bahwa sebagai dokter, kita justru merupakan pihak yang rentan dan gampang tertular COVID-19. Untuk itu selama proses pelayanan pasien kita harus selalu menjaga jarak, mengenakan masker demikian juga selama di rumah kita harus menjaga keluarga kita dari penularan virus ini.

Mudah mudahan wabah COVID-19 ini cepat berlalu bukan hanya di Indonesia, tetapi diseluruh dunia sehingga kehidupan kita sebagai tenaga medis dapat kembali seperti sedia kala. Insyaallah

(ISSN 2723-7494 J Bedah Indonesia. 2020;48:1-2)

Korespondensi Penulis:

Patrianef Darwis

Divisi Bedah Vaskular dan Endovaskular. Departemen Ilmu Bedah Fakultas Kedokteran

Universitas Indonesia

Rumah Sakit Cipto Mangunkusumo

email : patrianef@gmail.com

ORCID ID OF AUTHORS

https://orcid.org/0000-0002-4982-903 